\title{
Analysis of the Implementation of e-Learning in Stain Sultan Qaimuddin Kendari Southeast Sulawesi
}

\author{
Ambar Sri Lestari
}

\begin{abstract}
This study aimed to describe the factors that influence the implementation of e-learning at STAIN Kendari. The method in this research is a descriptive qualitative the data analysis consists of data reduction, data presentation, conclusions and verification while the validity of data by triangulation of data. Development of e-learning can be accessed at http://www.elearning-ambarsrilestari.web.id/. Based on the analysis of field data, it was found that the the factors that influence the implementation of e-learning at STAIN include: 1) the use of e-learning is not yet a culture of learning 2) limited human resources in the field of information technology both faculty and staff 3 ) wifi network cannot be accessed directly in the classroom, and 4) low students' understanding of information technology in learning.
\end{abstract}

Index Terms-E-learning, learning culture, information technology.

\section{INTRODUCTION}

STAIN Sultan Qaimuddin Kendari is an Islamic State University located in the province of Southeast Sulawesi. During this learning is done by conventional methods such as face to face in the classroom between teachers and students with discourse and discussion. For two years the author observed that the learning in the classroom are less variation because there is no touch of technological innovation in media element in the learning process. That's why the authors develop an e-learning that has been used for two years, e-learning can be acces in http://www.elearning-ambarsrilestari.web.id/. The development of e-learning is supported by application systems Learning Management System as a software with Moodle as the open source program. E-learning has not been applied to all subjects, the authors develop an e-learning as the instructional media in the learning process, so that students will be familiar with technology as a part of learning and make a new culture of learning. So far, the authors combine the asynchronous and synchronous learning, which cannot be separated from the constraints that exist in the field. For this reason the authors are encouraged to find out how the factors influencing the implementation of e-learning and student responses in learning.

\section{TEACHING BASED E-LEARNING}

E-learning is the use of electronic media, educational

Manuscript received October 2, 2014; revised December 29, 2014.

Ambar Sri Lestari is with STAIN Sultan Qaimuddin Kendari, Indonesia (e-mail: ambarlstr@gmail.com). technology information and communication technologies. Soekartawi and Haryono [1], say that $e$ - learning is a generic term for all technologically supported learning using an array of teaching and learning tools as phone bridging, audio and videotapes, teleconferencing, satellite transmissions, and the more recognized web-based training or computer aided instruction also commonly referred to as online courses. Implementation of learning-based e-learning at least two, which is the first learning-based e-learning is organized in a simple, just a collection of learning materials are loaded in a web server with forum for communication via email or mailing list. Secondly, integrated through an e-learning portal that contains a variety of learning objects are enriched with multimedia and information systems combined with academic, evaluation, communication, discussion and various other tools of education. E-learning system can be implemented in the form of asynchronous, synchronous, or a mixture of both. Examples of synchronous e-learning are often found on the internet either simple or integrated through e-learning portal, whereas the synchronous e-learning faculty and students should be in front of the computer together because the learning process carried live, either through video and audio conferencing. The use of both called blended learning which combines all forms of learning such as online learning, live and face to face.

E-learning is a useful tool for enhancing the quality of teaching and learning. E-learning is an "innovative approach to education delivery via electronic forms of information that enhance the learner's knowledge, skills, or other performance" Siritongthaworn, [2]. E-learning as the use of the internet by users to learn specific content. Other researchers define e-learning as using modern Information and Communications Technology and computers to deliver instruction, information, and learning content, Selim [3]. There are some important factors that influence the success of e-learning, according to Selim that faculty, students, and supporting technologies.

E-learning environment refers to where students access online resources, use systems for access to online curriculum and communication, obtain tutor assistance, and receive assessment, Lennon \& Maurer [4]. Successful outcomes of e-learning include providing opportunities for interactions, facilitating the exchange of information among learners and instructors, synchronous and asynchronous communication, and online assessment, Cao, Griffin, and Bai, [5]. Online interactions among learners as well as between learners and instructors increase learners' participation in educational activities, Swan [6]. An e-learning environment also includes instruction and university support. A positive e-learning environment contributes to e-learning success, factors 
relevant for a positive e-learning environment include social influence, learners' perceived interactions with others, diversity in assessment, and perceived autonomy support Roca and Gagné [7].

\section{AsPeCt PEDAGOGY OF E-LEARNING}

Pedagogy is how to teach the children, where as and ragogy is how to teach adults (see Fig. 1). Bjorke [8], propose a model of an integrated approach to pedagogy consisting of instructional approach, constructivist and social constructivist. Third approach was adopted in an integrated pedagogy in e-learning system (see Table I).

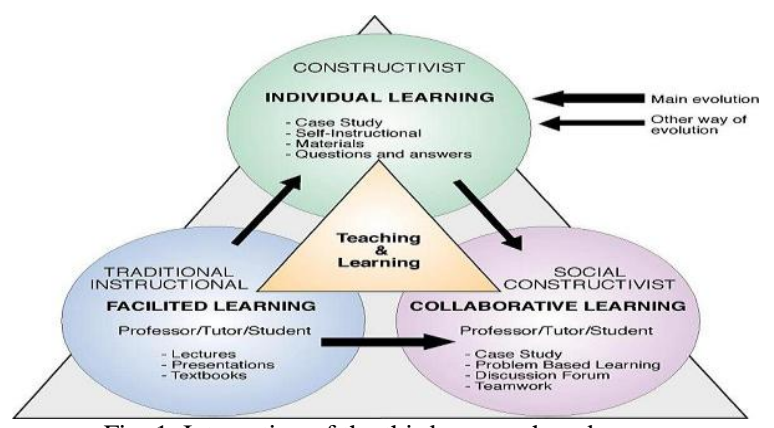

Fig. 1. Integration of the third approach pedagogy.

TABLE I: THE LiNK BETWEEN THE CHARACTERISTICS OF EACH PEDAGOGY WITH THE TECHNOLOGY E-LEARNING

\begin{tabular}{|c|c|c|c|c|}
\hline Type of Pedagogy & Characteristics & Features of LMS & Content & Delivery Methode \\
\hline \multirow[t]{4}{*}{$\begin{array}{l}\text { Instructional } \\
\text { (facilitated learning) }\end{array}$} & Traditional, teacher-focused & $\begin{array}{l}\text { Facility to store learning } \\
\text { materials }\end{array}$ & Teks, picture, audio, video & \multirow{4}{*}{$\begin{array}{l}\text { The meeting face to face (face to } \\
\text { face). } \\
\text { Student as a listener. }\end{array}$} \\
\hline & Learners dependent on teacher, & Question posted via e-mail & & \\
\hline & $\begin{array}{l}\text { Learners as rather passive } \\
\text { receptors }\end{array}$ & $\begin{array}{l}\text { Learning materials are } \\
\text { available in every session }\end{array}$ & $\begin{array}{l}\text { Learning materials related } \\
\text { links }\end{array}$ & \\
\hline & $\begin{array}{l}\text { Sees "knowledge" as fairly } \\
\text { static and objective. }\end{array}$ & $\begin{array}{l}\text { Learning sessions can be } \\
\text { added as needed }\end{array}$ & $\begin{array}{l}\text { Design materials } \\
\text { sillaby }\end{array}$ & \\
\hline \multirow{5}{*}{$\begin{array}{l}\text { Constructivist } \\
\text { (individual learning) }\end{array}$} & Active learners. & Discussion forum & Material triggers & \multirow{5}{*}{$\begin{array}{l}\text { Meetings electronically. } \\
\text { Lecture as facilitator. } \\
\text { Feedback Lecturer in accordance } \\
\text { with the progress of student } \\
\text { learning. } \\
\text { Control There on student }\end{array}$} \\
\hline & $\begin{array}{lll}\text { Learners } & \text { construct } & \text { their } \\
\text { knowledge }\end{array}$ & Notes taking & $\begin{array}{lll}\begin{array}{l}\text { Guided } \\
\text { answers }\end{array} & \text { question and } \\
\end{array}$ & \\
\hline & $\begin{array}{lll}\text { Subjective, dynamic } & \text { and } \\
\text { expanding }\end{array}$ & $\begin{array}{l}\text { Pointes to other sources of } \\
\text { learning }\end{array}$ & Other sources of learning & \\
\hline & $\begin{array}{l}\text { Processing and understanding } \\
\text { of information }\end{array}$ & Pace setting & $\begin{array}{lcr}\begin{array}{l}\text { Sequence } \\
\text { materials }\end{array} & \text { of } & \text { learning } \\
\text { content) } & & \\
\end{array}$ & \\
\hline & Learner has his own learning. & Personalization & $\begin{array}{lr}\begin{array}{l}\text { Setting } \\
\text { objectives } \\
\text { assessment) }\end{array} & \begin{array}{r}\text { Learning } \\
\text { (graph }\end{array} \\
\end{array}$ & \\
\hline \multirow{3}{*}{$\begin{array}{l}\text { Social Constructivist } \\
\text { (collaborative } \\
\text { learning) }\end{array}$} & $\begin{array}{l}\text { Student joins a knowledge } \\
\text { Generating }\end{array}$ & Chat mode & Case study & \multirow{3}{*}{$\begin{array}{l}\text { Video conference. } \\
\text { The meeting electronically through } \\
\text { chat mode. } \\
\text { Lecturers and tutors as facilitators. } \\
\text { Were divided into the several } \\
\text { groups - team work. }\end{array}$} \\
\hline & Solve real problems & Chat mode & $\begin{array}{l}\text { Pointer to other related } \\
\text { sources }\end{array}$ & \\
\hline & $\begin{array}{l}\text { Teacher will himself be a } \\
\text { learner together with his } \\
\text { students. }\end{array}$ & Video conference & $\begin{array}{l}\text { Pointer to other related } \\
\text { sources }\end{array}$ & \\
\hline
\end{tabular}

\section{RESEARCH METHODS}

This study used a qualitative descriptive approach. The data to be collected are the factors that influence e-learning and student responses in implementation of e-learning in STAIN Kendari. The data source consists of primary and secondary data. The primary data source is derived from observation and interviews to students who have followed the learning with e-learning. Secondary data came from of literature related to the topic. Informants were determined using snow-ball technique, extracting the data through in-depth interviews from one informant to another informant, and so on until the researchers did not find any new information again. Analysis of the data used by researchers using Miles Huberman [9] interactive analysis, which consists of data reduction, data presentation and with draw as well as the conclusion of testing. While for checking the validity of the data through the data triangulation techniques (source) that the researcher attempts to access data sources relating to the same subject.

\section{RESULTS AND DISCUSSION}

The factors influencing the implementation of e-learning in STAIN Sultan Qaimuddin Kendari, including:

\section{A. Technology}

The development of e-learning is use software Learning Management System by Moodle. Learning Management System is the environment used by teachers / instructors in creating, storing, using, managing and delivering learning materials to students, which is software to make the course materials on-line (web-based) that supports a variety of activities, including: administration, delivery of learning materials, assessment (assignments, quizzes), tracking / tracking \& monitoring, collaboration, and communication / interaction. Moddle is Modular Object Oriented Dynamic Learning Environment, is a software package produced for an internet-based learning activities and web sites that use the principle of social constructionist pedagogy is one of the applications of the concepts and learning mechanisms that use 
information technology. E-learning has been carried out in an integrated manner that is integrated on the portals to support such a stain Kendari portals that can be accessed directly through e-learning. However, information systems still offline or local academic campus not connected online.

\section{B. Infrastructure}

Infrastructure related to the changing concept of the conventional learning to be online, it is being developed in the area of campus in the internet network infrastructure upgrade. Currently the internet is in the third area of the campus with $10 \mathrm{Mbps}$ bandwidth force scattered at several access points, including: a). Rectorate Building (3 points), b). Da'wah Building (1 point), c). Tarbiyah Building (2 points), d). Syaria Building (1 point), e). Library Building (1 point), f). P2M Building (1 point), g). Labarotorium Language Building (1 point), h). Computer Laboratory Building (1 point). In addition there is a LAN connection on the computer $95 \%$ administrative staff, while an integrated access point to the building that is used for classes so there is no use wifi on campus in eight areas.

\section{Human Resources}

Source of funds is also very important in the development of internet-based learning, in addition to requiring sizable investment funds also requires human resources that can operationalize e-learning. Computer technician is needed as an operator in maintaining e-learning in order to be used properly. In addition, the ability of lecture to use e-learning is also very important because the lecturer is the person who will lead in the use of e-learning during the learning process, students should also be able to use technology in e-learning, so that there will be no misunderstandings in acceptance of e-learning as a learning medium. The staff who have expertise in information technology only one person so much his duty to make the internet not as an operator campus needs in e-learning, in addition only one person as lecture who teach the course media with e-learning personally. Not all students understand the learning of technology, the internet is still limited to the use of social media facebook and email, but it was still a student there is also no particular use blogs as a medium for learning. The students have email and blogs as a means for sharing knowledge.

\section{The Response of Students to the Implementation of e-Learning}

Student responses during the development of e-learning means learning media made for very diverse. Previous studies researchers have asked some point in the use of e-learning in terms of feasibility and comfort are (see Table II):

TABLE II: APPROPRIATENESS AND CONVENIENCE OF E-LEARNING USE

\begin{tabular}{|l|l|}
\hline No & Items \\
\hline 1 & Use of domain name http://www.elearning-ambarsrilestari.web.id/ easy to be accessed and used in e-learning system \\
\hline 2 & Use of domain name which is easy to remember and use by the users \\
\hline 3 & Access hosting speed http://www.elearning-ambarsrilestari.web.id/ \\
\hline 4 & Access speed per website page \\
\hline 5 & Login speed to system \\
\hline 6 & Download speed PDF material file \\
\hline 7 & Video loading speed \\
\hline 8 & Delivery of interesting and understandable quiz \\
\hline 9 & Layout display of interface website design for use of online learning media \\
\hline 10 & Website features served appropriately which is suitable and very beneficial for website users \\
\hline 11 & Layout of material file in website layout \\
\hline 12 & Size of writing clear to read and see \\
\hline 13 & Aesthetics of e-learning banner which is interesting and visible \\
\hline 14 & Simplicity in use of website navigation \\
\hline 15 & Using this learning media can broaden your horizon and knowledge \\
\hline 16 & Is this online media appropriate for learning media? \\
\hline 17 & Name of logo \\
\hline
\end{tabular}

Table III explains that system development e-learning based on the user needs:

1) Information about units related in the learning process teaches, there are: goals and objectives, syllabus, methods of teaching, class schedules, task, exam, list of reference or reading material, profile and contact teachers

2) Ease of access to reference sources, there are: useful websites, easy to acces, presentation materials, examples of past exams, sources of reference.

3) Communication in the classroom, there are: an online discussion forum, mailing list discussion, assignments and deadlines information

4) Means to conduct group work, there are: means for sharing files and directories in the group, means of discussion for working on assignments in groups, and systems online exam and gathering feedback

\section{E. Learning Culture}

The e-learning is done for two years of learning, the students is still needs to introduce in order to understand the use of e-learning in the learning process either synchronously or asynchronously. The lecture requires students to use email and blog as a means of learning media. Establishment of learning with e-learning will be able to change the mindset of students, lecturers so that the future of e-learning can be an institutional policy to use them in the learning process, which is currently done in stages, namely by improving and expanding Internet access to the lecture hall, in addition to the need for training provided to faculty to be able to use information technology in the learning process. The implementation of e-learning is done in the learning refers to the opinion of Haughey [10] on the development of internet-based learning system, which is a web enhanced course where the use of the Internet for education and position 
as supporting an increase in the quality of teaching and learning activities in the classroom. This form also known as Web lite course, because the primary instructional activities are face to face in the classroom. The role of the internet here is to provide resources to facilitate knowledge enrichment address information or make connections (links) to a variety of learning resources are appropriate and which can be accessed online.

TABLE III: SYSTEM DEVELOPMENT OF E-LEARNING

\begin{tabular}{|c|c|c|}
\hline No & Assessment & Information \\
\hline 1 & $\begin{array}{l}\text { The use of the domain name } \\
\text { http://www.elearning-ambarsrilestari.web.id/ easy to } \\
\text { acces and used in e-learning system }\end{array}$ & $\begin{array}{l}\text { Based on the test results of the feasibility of using a domain name is } \\
\text { quite easy to find }\end{array}$ \\
\hline 2 & $\begin{array}{l}\text { The use of a domain name is easy to remember and is } \\
\text { used by the user domain }\end{array}$ & Name is easy to remember \\
\hline 3 & $\begin{array}{l}\text { Http://www.elearning-speed access hosting } \\
\text { ambarsrilestari.web.id/ }\end{array}$ & Hosting speed somewhat constrained network signal fast enough \\
\hline 4 & Speed of access to every page of the website & The material can be accessed to quickly on a web page \\
\hline 5 & Speed log into the system & Speed login to get on the e-learning can be done quickly \\
\hline 6 & PDF file download speeds matter & To download a file can be done quickly \\
\hline 7 & Video loading speed & $\begin{array}{l}\text { Because the video is loaded on the system comes from } \\
\text { www.youtube.com. then do not use the bandwidth of the hosting but the } \\
\text { bandwidth of youtube so dependent loading speed network }\end{array}$ \\
\hline 8 & Submission quiz interesting and easy to understand & $\begin{array}{l}\text { Questions on the quiz can be easily understood and in answering } \\
\text { questions through an online }\end{array}$ \\
\hline 9 & online learning media & Using the appropriate color logo design campus \\
\hline 10 & $\begin{array}{l}\text { The features of websites that served proper, appropriate } \\
\text { and very useful to the users of the website }\end{array}$ & $\begin{array}{l}\text { It is indeed reactors are drafted before building a website. So the } \\
\text { features shown are adequate for learning }\end{array}$ \\
\hline 11 & The layout of the material in the website layout files & $\begin{array}{l}\text { The layout of the file material is in conformity with Reviews their } \\
\text { own kind }\end{array}$ \\
\hline 12 & The size of the writing is clear to read and see & The font used already as needed \\
\hline 13 & $\begin{array}{l}\text { Aesthetics banner of e-learning attractive and clearly } \\
\text { seen }\end{array}$ & Aesthetics is feasible, attractive and clear \\
\hline 14 & Ease of use of website navigation & Navigation is easy to use \\
\hline 15 & $\begin{array}{l}\text { By using this learning media can add insight and } \\
\text { knowledge you }\end{array}$ & $\begin{array}{l}\text { It is clear, students using this system means empowering technology } \\
\text { in education }\end{array}$ \\
\hline 16 & Eligible online media is used to study media & $\begin{array}{l}\text { There are many who agree this system is used as a medium of } \\
\text { learning }\end{array}$ \\
\hline 17 & The use of the name of the agency conveyed clearly & In the name of the institution is clear logo on the system \\
\hline
\end{tabular}

\section{CONCLUSIONS}

Web enhanced course is the utilization of the internet to support the improvement of the quality of learning in the classroom. The roles of teachers are required to master technique of searching for information on the internet, presents the material through a web attractive and desirable. E-Learning is used as a tool in teaching with technology, Learning using e-learning as a source of teaching material is still being done with face-to-face (during the learning process). E-learning can occur in or out of the classroom. It can be self-paced, asynchronous learning or may be instructorled, synchronous learning. E-learning is suited to distance learning and flexible learning, but it can also be used in conjunction with face-to-face teaching, in which case the term blended learning is commonly used.

\section{REFERENCE}

[1] S. Soekartawi, A. Haryono, and F. Librero, "Greater learning opportunities through distance education: Experiences in Indonesia and the Philippines," Southeast Journal of Education, vol. 3, no. 2, p. 56, 2012.

[2] S. Siritongthaworn, D. Krairit, N. J. Dimmitt, and H. Paul, "The study of e-learning technology implementation: A preliminary investigation of universities in Thailand," Education and Information Technologies, vol. 11, no. 2, pp. 137-139, 2006

[3] H. M. Selim, "Critical success factors for elearning acceptance: Confirmatory factor models," Comput. Educ., vol. 49, no. 2, pp. 49, 396-413, 2007.
[4] J. Lennon and H. Maurer, "Why it is difficult to introduce e-learning into schools and some new solutions," Journal of Universal Computer Science, vol. 9, no. 10, 2003, pp. 1244-1257.

[5] Q. Cao, T. E. Griffin, and X. Bai, "The importance of synchronous interaction for student satisfaction with course web sites," Journal of Information Systems Education, vol. 20, no. 3, pp. 331-338, 2009.

[6] K. Swan, "Virtual interaction: Design factors affecting student satisfaction and perceived learning in asynchronous online courses," Distance Education, vol. 22, no. 2, pp. 306-331, 2001.

[7] J. C. Roca and M. Gagné, "Understanding e-learning continuance intention in the workplace: A self-determination theory perspective," Computers in Human Behavior, vol. 24, no. 4, pp. 1585-1604, 2008.

[8] A. Bjørke, "Global cooperation on e-learning: Background and pedagogical strategy," United Nations University/Global Virtual University, 2005, p. 20.

[9] M. B. M. dan H. A. Maichhel, Analysis of Qualittive Data, Source of the New Methods, UI-Press Jakarta, 1992, p. 20.

[10] M. Haughey and T. Anderson, Networked Learning: The Pedagogy of the Internet, Montreal: Cheneliere/McGraw-Hill, 1998.

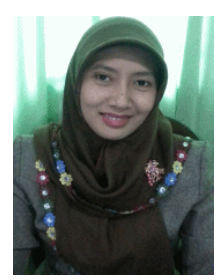

Ambar Sri Lestari was born on June 2, 1978 in Surabaya. Her background educational is doctor management of education in Jakarta State University. She is a lecturer at STAIN Sultan Qaimuddin Kendari Southeast Sulawesi Indonesia from 2011. Her first research is development e-learning with learning management system based on moodle on learning media subject in 2013 and the second research is analysis of e-learning as knowledge sharing on learning. Her first publisher of book is Application Moodle in e-Learning by Orbit Publishing Jakarta 2014. Dr. Lestari is a member of institues STAIN Sultan Qaimuddin Kendari. 